\title{
POLA KOMUNIKASI KESANTUNAN DAN KETAKSANTUNAN BERBAHASA ANTARA MAHASISWA DENGAN DOSEN (STUDI KASUS SOSIOPRAGMATIK) DI STKIP BUDIDAYA BINJAI
}

\author{
Sri Kurnia Hastuti Sebayang, Prina Yelli, \\ Dosen STKIP Budidaya Binjai
}

\author{
Dibiayai Oleh : \\ Direktorat Riset dan Pengabdian Masyarakat \\ Direktorat Jenderal Penguatan Riset dan Pengembangan \\ Kementrian Riset, Teknologi dan Pendidikan Tinggi \\ Sesuai dengan Kontrak Tahun Anggaran 2018
}

\begin{abstract}
ABSTRAK
Penelitian ini bertujuan untuk memaparkan pola komunikasi kesantunan dan ketaksantunan berbahasa antara mahasiswa dan dosen di STKIP Budidaya Binjai. Jenis penelitian ini termasuk deskriptif kualitatif. Data penelitian berupa satuan lingual tindak tutur direktif, baik dalam suasana formal ataupunnon formal di dalam kampus STKIP Budidaya Binjai. Adapun sumber data meliputi aktivitas mahasiswa dan dosen. Teknik pengumpulan data menggunakan teknik observasi langsung, lembar wawancara, dan angket. Analisis data menggunakan metode triangulasi. Faktor konteks juga menyebabkan kesantuan berbahasa perlu diterapkan.

Suasana formal atau resmi sangat menekankan kesantuan berbahasa bagi pemakainya. Dengan kata lain, bahasa tidak saja dipandang sebagai gejala individual, tetapi juga merupakan gejala sosial, termasuk fenomena kesantunan berbahasa Indonesia di lingkungan mahasiswa STKIP Budidaya Binjai. Kecenderungan dosen melakukan tindak tutur direktif bertanya berkaitan dengan kesopanan dan ketaksopanan berbahasa yang diutarakan mahasiswa dalam setiap jawaban yang diutarakan mahasiswa pada konteks situasi tutur yang berkaitan dengan perkuliahan, pengajuan judul skripsi, dan hal akademik lainnya. Dosen mengajukan pertanyaan dan respon tindak tutur balasan mahasiswacenderung ke arah yang memilikikesopanan daripada ketidaksopanan. Mahasiswa mampu menggunakan tindak tutur direktif kesopanan berbahasa dengan menghargai dan suasana yang tenang dan santai. Ada beberapa tuturan yang disampaikan berkaitan dengan ketidaksopanan tetapi hanya sebagian kecil. Teknik analisis data dengan menggunakan triangulasi menghasilkan tindak tutur direktif yang dilakukan dalam berkomunikasi lebih banyak menggunakan kesopanan berbahasa daripada ketaksopanan berbahasa.
\end{abstract}

Kata Kunci : Pola komunikasi, kesantunan berbahasa, dan sosiopragmatik 


\section{PENDAHULUAN}

Bahasa pada dasarnya

merupakan alat untuk berkomunikasi masyarakat pemakainya. Melalui bahasa, aktivitas berkomunikasi terasa lebih mudah dan efektif. Oleh karena itu, masyarakat tutur harus selalu memperhatikan pola komunikasi dalam berbahasa sehingga tidak terjadi hal-hal yang dapat menimbulkan kesalahpahaman antar mitra tutur tersebut.

Tata cara berbahasa, termasuk santun berbahasa sangat penting diperhatikan oleh peserta komunikasi untuk kelancaran komunikasinya. Misalnya, dalam masyarakat Jawa, seorang penutur tidak akan menyatakan maksudnya hanya dengan mengandalkan pikirannya, tetapi yang lebih penting adalah perasaannya (angon rasa). Hal tersebut merupakan komunikasi yang dilakukan dengan menjaga perasaan mitra tutur. Meskipun, informasi yang disampaikan didukung oleh data dan kenyataan, tetapi jika waktu menyampaikannya tidak tepat, harus ditunda terlebih dahulu. Jika prinsip ini dilanggar, kemungkinan besar komunikasi dapat gagal mencapai tujuan (Pranowo, 2009:45). Hal ini tidak hanya terjadi dalam komonukasi sosial, tetapi juga dalam komunikasi formal (komunikasi akademik) supaya selalu tercipta suasana tutur yang harmonis.

Bahasa yang digunakannya sering memancing emosi seseorang sehingga menimbulkan keributan atau perselisihan, termasuk fenomena berbahasa di kalangan mahasiswa yang menanggalkan nilai-nilai kesantunan berbahasa sebagai akibat pergeseran nilai di tengah masyarakat yang semakin mengglobal ini.

Dengan kata lain, bahasa tidak saja dipandang sebagai gejala individual, tetapi juga merupakan gejala sosial, termasuk fenomena kesantunan berbahasa di lingkungan mahasiswa STKIP Budidaya Binjai. Dalam hal ini kesantunan dan ketaksantunan berbahasa akan dibatasi pada bentuk tuturan direktif di lingkungan STKIP Budidaya Binjai.

Konsep tindak tutur merupakan salah satu konsep yang paling menonjol dalam teori linguistik masa kini (Abdul Syukur Ibrahim, 1993:255). Konsep ini membawa upaya ilmiah ke arah fungsi bahasa dalam komunikasi manusia. Dalam melaksanakannya konsep ini memungkinkan kombinasi berbagai bidang dan metode, baik linguistik maupun penelitian filosofis (Abdul Syukur Ibrahim, 1993:255).

Tindak tutur merupakan analisis pragmatik, yaitu bidang kajian linguistik yang mengkaji bahasa dari aspek pemakaian aktualnya. Geoffrey Leech (1993:6-7) menyatakan bahwa pragmatik mempelajari maksud ujaran (untuk apa ujaran itu dilakukan), 
menyatakan apa yang seseorang maksudkan dengan suatu tindak tutur, dan mengaitkan makna dengan siapa berbicara kepada siapa, di mana, bilamana, dan bagaimana.

Prinsip kesantunan dalam bertindak merupakan hal yang menjadi dasar untuk keberhasilan dalam pembicaraan antara penutur dan mitra tutur yang bersifat positif. Fraser dalam Asim Gunarwan (2007:1880 mendefinisikan kesantunan, dalam hal ini kesantunan berbahasa adalah properti yang diasosiasikan dengan ujaran dan si penutur tidak melampaui hak-haknya atau tidak mengingkari untuk memenuhi kewajibannya. Sementara itu, menurut Lakoff dalam Asim Gunarwan (2007:187) sebuah ujaran dikatakan santun apabila ia tidak terdengan memaksa atau angkuh, ujaran itu memberi pilihan tindakan kepada lawan bicara, dan lawan bicara itu menjadi senang. Masnur Muslich (2006:12) menyatakan bahwa kesantunan (politines) adalah tata cara, adat atau kebiasaan yang berlaku dalam masyarakat. Kesantuan merupakan aturan perilaku yang ditetapkan dan disepakati bersama oleh suatu masyarakat tertentu sehingga kesantunan sekaligus prasyarat yang disepakati oleh perilaku sosial.

Masnur Muslich (2010) menyatakan bahwa kesantuan dapat dilihat dari berbagai segi dalam kehidupan sehari-hari. Pertama, kesantuan memperlihatkan sikap yang mengandung nilai sopan santun atau etikket dalam pergaulan sehari-hari. Ketika orang dikatakan santun, dalam diri seseorang itu tergambar nilai sopan santun yang berlaku baik di masyarakat tempat seseorang itu mengambil bagian sebagai anggotanya. Kedua, kesantunan sangat kontekstual, yakni berlaku dalam masyarakat, tempat, atau situasi tertentu, tetapi belum tentu berlaku bagi masyarakat, tempat, atau situasi lain. Ketiga, kesantuan selalu bipolar, yaitu memiliki hubungan dua kutub, seperti antara anak dan orang tua, antara orang yang masih muda dan orang yang lebih tua, antara tuan rumah dan tamu, antara pria dan wanita, antara murid dan guru. Keempat, kesantunan tercermin dalam cara berpakaian, cara berbuat, dan cara bertutur.

Berdasarkan berbagai pendapat di atas, dapat disimpulkan bahwa kesantunan berbahasa itu adalah tata cara atau etiket berbahasa yang ditetapkan dan disepakati bersama oleh suatu masyarakat tertentu dengan memperhatikan kaidah (kaidah sosial) dan pemilihan strategi agar komunikasi berjalan lancar dan harmonis. Kesantunan berbahasa tersebut bergantung pada sosial budaya, norma, dan aturan di suatu tempat sehingga nilai atau aturan satu budaya dapat berbeda dengan budaya lain. 


\section{METODE PENELITIAN}

Penelitian ini menggunakan pendekatan kualitatif. Pendekatan kualitatif akan mampu menangkap berbagai informasi kualitatif dengan deskripsi teliti dan penuh nuansa yang lebih berharga daripada sekadar pernyataan jumlah atau frekuensi dalam bentuk angka.

Teknik pengumpulan data dalam penelitian ini, antara lain dengan teknik observasi, wawancara secara mendalam, dan angket. Data yang diambil dalam penelitian ini adalah data lisan, baik dosen maupun mahasiswa di lingkungan STKIP Budidaya Binjai. Dalam pengumpulan data tersebut dilakukan pencatatan atau pendokumentasian data dengan memindahkan data-data tuturan ke dalam kartu data yang sudah dipersiapkan. Penggunaan alat bantu berupa kartu dasar tersebut memberikan kemungkinan bekerja secara sistematik karena mudah diklasifikasikan atau dikategorikan secara fleksibel.

Teknik analisis data dalam penelitian ini dilakukan dengan triangulasi,untuk mengategorikan komunikasi antara dosen dan mahasiswa masuk ke ranah kesopanan atau ketaksopanan dalam berbahasa. Tempat atau lokasi penelitian dilakukan di STKIP Budidaya Binjai. Kampus tersebut dijadikan tempat untuk menjaring data yang berkaitan dengan objek penelitian, baik di dalam kelas maupun di luar kelas. Peristiwa yang menjadi sumber data dalam penelitian ini adalah peristiwa-peristiwa tindak tutur kesantuan dan ketaksantunan berbahasa yang terjadi antarmahasiswa, antara mahasiswa dan dosen.

Sumber data penelitian ini dikumpulkan dengan cara lokasional (Sudaryanto, 1993:33-34), yaitu tempat asalnya data yang merupakan si pencipta bahasa atau penutur sebagai informan atau narasumber. Sumber data dalam penelitian ini adalah sumber lisan. Data lisan, yaitu kesantuan dan ketaksantunan berbahasa mahasiswa di lingkungan Program Studi STKIP Budidaya Binjai. Sumber data lisan tersebut bersifat natural. Natural tersebut adalah penggunaan atau peristiwa bahasa yang terjadi (berlangsung) secara alami atau wajar, tanpa dibuat-buat oleh penutur dalam komunikasinya.

Informan (narasumber) dalam penelitian ini adalah orang yang dapat memberikan keterangan mengenai data bahasa yang diperlukan dalam penelitian. Dalam hal ini, informannya adalah mahasiswa, dosen. Informan tersebut akan diobservasi penggunaan bahasanya, baik melalui wawancara maupun dengan pengamatan secara langsung di lingkungan kampus STKIP Budidaya Binjai.

Adapun penentuan subjek yang dimaksud di sini adalah pemilihan terhadap data lisan, yaitu berupa kata, frasa, kalimat, ataupun istilah yang membentuk wacana lisan 
sesuai dengan objek kajian berdasarkan latar latar situasi di lingkungan mahasiswa STKIP Budidaya Binjai.

Validasi data merupakan kebenaran dari proses penelitian. Data yang telah dikumpulkan di atas, selanjutnya akan dilakukan triangulasi sumber. Teori dan data dari berbagai sumber ditriangulasikan berdasarkan berbagai sumber untuk menjaga untuk menjaga validitas data yang dikumpulkan dalam penelitian. Menurut H.B. Sutopo (2003:82) trianggulasi teori dilakukan dengan menggunakan perspektif lebih dari satu teori dalam membahas permasalahan yang dikaji. Dalam hal ini dengan mengumpulkan data sejenis dengan menggunakan berbagai sumber data yang berbeda.

\section{HASIL DAN PEMBAHASAN}

Penelitian ini ini mengkaji data dari temuan pola komunikasi kesantunan dan ketaksantunan berbahasa antara mahasiswa dan dosen di STKIP Budidaya Binjai. Selanjutnya akan dikaitkan dengan implikasinya terhadap kajian mata kuliah sosiopragmatik di Program Studi Pendidikan Bahasa dan Sastra Indonesia STKIP Budidaya Binjai. Berdasarkan analisis data, ditemukan beberapa hasil dan pembahasan yaitu

1. Observasi langsung kepada beberapa mahasiswa

Tindak tutur direktif bertanya

Dosen : kenapa kamu terlambat

Mahasiswa A : (datang mendekat) ada gangguan tadi di sana $\mathrm{Bu}$, ban. kereta saya bocor

Dosen : : kenapa kamu terlambat

Mahasiswa B : ( tetap berdiri di depan pintu) ketiduran tadi $\mathrm{Bu}$

Dosen : kapan akan kita kumpulkan Krs dan Khsnya

Mahasiswa : : kalau bisa habis selesai sidang aja ya $\mathrm{Bu}$

(bentuk pola komunikasi penawaran)

Tuturan terjadi pada saat mahasiswa terlambat masuk ke dalam ruangan kelas, saat dosen sudah memulai kegiatan belajar mengajar, pertemuan awal perkuliahan Dosen dan mahasiswa sudah menyetujui kontrak kuliah bahwa kalau terlambat 15 menit maka tidak diperbolehkan masuk ke dalam ruangan. 
Mahasiswa : (berdiri dan datang ke depan meja dosen) kalau mengajukan judul skripsi harus dibawa referensinya ya Bu

Dosen : Iya sebagai dasar kan biar kuat dasar dosen menyetujui judul skripsi kamu

2. Lembar Wawancara

Dosen : Bagaimana cara Anda menjawab perintah dosen ketika Anda dipersilahkan keluar dari ruangan berkaitan dengan keterlambatan Anda datang untuk mengikuti perkuliahan.

Mahasiswa : Saya akan menjawab iya bu dan keluar dari ruangan

Dosen : Jika dosen meminta tolong untuk menghidupkan infokus dan laptop sebelum KBM berlangsung, maka apa yang akan Anda lakukan. Mahasiswa $\quad$ : Melaksanakan atau mengerjakan perintah dosen

Dosen : Bagaimana bahasa yang Anda ungkapkan ketika Anda bertanya tentang dosen yang belum hadir pada jam perkuliahan, sementara pertemuan sebelumnya dosen sudah memberi tugas untuk dipresentasikan pada pertemuan hari ini.

Mahasiswa : Meneloponnya, lalu memberi salam Assalamualaikum bu, maaf mengganggu waktunya. Ini Tuti alwiyah dari kelas VIIIA. Ibu datang hati ini Kami sepertinya tidak bisa presentasi tanpa ada dosen bu... lalu gimana jadinya presentasi kita hari ini bu

Dosen : Apa yang akan Anda ungkapkan kepada Dosen yang meminta tolong untuk memotocopikan berkas sementara Anda ada KBM di kelas.

Mahasiswa : Iya bu, sebentar lagi ya.. Tuti masih ada jam. Nanti Tuti Jumpai Ibu di ruangan Ibu

Dosen : Bagaimana cara Anda untuk mengutarakan keluhan tugas atau materi yang sulit untuk didapatkan.

Mahasiswa $\quad$ : Bu susah kali tugasnya, susah nyarinya. Dikumpul minggu depan aja ya $\mathrm{Bu}$ 
Dosen : Ketika Anda mengajukan judul skripsi ke dosen pembimbing, judul Anda diminta dosen untuk diganti, apa respon Anda. Mahasiswa $\quad$ : Bu, Tuti Cuma menguasai judul yang ini. Kaau ganti belum tentu Tuti menguasainya $\mathrm{Bu}$

Dosen : Bagaimana cara Anda menelpon Dosen untuk menanyakan apakah akan ke kampus atau tidak karena Anda mau bimbingan skripsi. Mahasiswa : saya akan memberi salam, Assalamualaikum Bu, Maaf mengganggu waktunya, Ibu datang ke kampus Saya mau bimbingan bu

Dosen : Bagaimana respon Anda ketika Dosen ingin menunjukkan bahwa banyak yang harus direvisi dalam skripsi Anda dan belum bisa disetujui. Mahasiswa : Sedikit kecewa, tapi memang itu yang terbaik supaya hasilnya lebih baik lagi.

Dosen : Siapakah dosen yang paling sering meminta tolong kepada Anda, bagaimana sebenarnya perasaan Anda ketika dimintai tolong oleh dosen tersebut.

Mahasiswa $\quad$ : Ibu Sri Kurnia Hastuti dan Ibu Tanita

Perasaan saya biasa saja karena saya merasa diperhatikan maka sering disuruh

Dosen : Bagaimana cara Anda berterima kasih kepada dosen pembimbing akademik dan juga pembimbing skripsi Anda setelah Anda selesai seminar proposal.

Mahasiswa : terima kasih atas bimbingan Ibu selama ini karena sudah banyak memberi ilmunya ke Tuti sampai selesai dengan bagus 


\section{DAFTAR PUSTAKA}

Abdul Chaer dan Leonie Agustina. 1995. Sosiolinguistik: Suatu Pengantar. Jakarta: Rineka Cipta.

A.Hamid hasan Lubis. 1993. Analisis Wacana Pragmatik. Bandung: Angkasa.

Aminudin Aziz. 2003. "Theorizing Linguistic Politness In Indonesia Sosiety" dalam Jurnal Linguistik Indonesia. Tahun ke-21 Nomor 1 Agustus 2004. hal 167-186.

Asim Gunarwan. 1994. "Persepsi Kesantunan Direktif di dalam Bahasa Indonesiadi antara Beberapa Kelompok Etnik di Jakarta”. Makalah PELLBA 5: Bahasa Budaya. Jakarta: Unika Atma Jaya. . 2007. Pragmatik Teori dan Kajian Nusantara. Jakarta: Penerbit Unika Atma Jaya.

Depdikbud. 1995. Teori dan Metode Linguistik I. Jakarta: Pusat Pembinaan dan Pengembangan Bahasa.

Geoffery Leech. 1993. Pragmatik. (Terj. M.D.D. Oka). Jakarta: UI Press.

Harun Joko Prayitno. 2001. "Tindak Tutur Pejabat dalam Peristiwa Rapat Dinas: Kajian Sosiopragmatik Berspektif Jender di Lingkungan Pemerintah Kota Surakarta" (Disertasi). Surakarta: PPs UNS

H.B. Sutopo. 2003. Metodologi Penelitian Kualitatif. Surakarta: UNS Press.

Hamid Hasan Lubis. 1993. Analisis Wacana Pragmatik. Bandung: Angkasa.

Herman J. Waluyo. 2008. Sosiolinguistik. Surakarta: PPs UNS.

Kunardi . 2000. "Ragam dan Sikap Bahasa Lurah: Penelitian Naturalistik di Kelurahan karangasem, Kotamadya Surakarta" (Disertasi). Jakarta: PPs UNJ.

Kunjono Rahardi. 2005. Pragmatik: Kesantunan Imperatif Bahasa Indonesia. Jakarta: Penerbit Erlangga.

Lexy Moleong. 2007. Metodologi Penelitian Kualitatif (Edisi revisi). Bandung: Remaja Rosdakarya.

Markhamah. 2009. Analisis Kesalahan dan Kesantunan Berbahasa. Surakarta : UMS Press.

Mahardika Zifana. 2010. Tindak Tutur. Dalam http://mahardhikazifana.com/linguisticlinguistik/tindak-tutur-pragmatik-berbahasa-html diunduh pada tanggal $20 \mathrm{Mei}$ 2010.

Masnur Muslih. 2006."Kesantuanan Berbahasa sebagai Pembentuk Kepribadian Bangsa" dalam http://researchengines.com/1006mansur2html diunduh pada tanggal $19 \mathrm{Mei}$ 2010. 
Mathew. B. Miles \& A. Michael Huberman. 2007. Analisis Data Kualitatif. (Terj. Tjetjep Rohendi Rosidi). Jakarta: UI Press.

Peter Trudgill. 1983. Sosiolinguistics an Introduction to Language and Society. England: Penguin Books.

Pranowo. 2009. Berbahasa Secara Santun. Yogyakarta: Pustaka Pelajar.

PWJ. Nababan. 1987.Ilmu Pragmatik: Teori dan Penerapannya. Jakarta: Depdikbud.

Sardiman. 2001. Interaksi dan Motivasi Belajar-Mengajar. Jakarta: Raja Grafindo Persada.

Saewiji Suwandi. 2008. Serba Linguistik: Mengupas Pelbagai Praktik Berbahasa. Surakarta: UNS Press.

Sudaryanto. 1993. Metode dan Aneka Teknik Analisis Bahasa. Yogyakarta: Duta Wacana University Press.

Sumarlam. 1995. "Skala Pragmatik dan Derajat Kesopansantunan dalam Tindak Tutur Direktif" dalam Komunikasi Ilmiah Linguistik dan Sastra (KLITIKA) Nomor 2 Tahun II. Agustus 1995.

Sumarsono dan Paina Partana. 2002. Kesopansantunan Berbahasa dalam Pergaulan. Surakarta: UNS Press

Suwito. 1997. Sosiopragmatik: Sebuah Pengantar. Surakarta: UNS Press.

Suyono. 1990. Sosiopragmatik: Dasar-dasar dan Pengajarannya. Malang: FPBS IKIP Malang.

Syamsul Anam. 2001. "Sopan Santun Berbahasa atau Sekadar Basa-Basi" dalam Jurnal Ilmu Bahasa dan Sastra (JBBS). Vol 1/ Nomor 2 Juli -Desember 2001. 